\title{
Dietary protein deprivation decreases the serine phosphorylation of insulin receptor substrate-1 in rat skeletal muscle
}

\author{
Y Toyoshima, Y Ohne, S-I Takahashi ${ }^{1}$, T Noguchi $^{2}$ and $\mathbf{H}$ Kato \\ Department of Applied Biological Chemistry, Graduate School of Agricultural and Life Sciences, The University of Tokyo, Bunkyo-ku, Tokyo 113-8657, \\ Japan \\ ${ }^{1}$ Departments of Animal Sciences and Applied Biological Chemistry, Graduate School of Agricultural and Life Sciences, The University of Tokyo, \\ Bunkyo-ku, Tokyo 113-8657, Japan \\ ${ }^{2}$ Department of Biological Chemistry, College of Bioscience and Biotechnology, Chubu University, Kasugai, Aichi 487-8501, Japan \\ (Requests for offprints should be addressed to H Kato; Email: akatoq@mail.ecc.u-tokyo.ac.jp)
}

\begin{abstract}
Evidence has shown that protein malnutrition tends to increase peripheral insulin sensitivity, but the molecular mechanism underlying this increase is not yet clear. Here we show that, in rat muscle, the state of insulin receptor (IR) substrate-1 (IRS-1), a pivotal component of the signaling pathway of the IR, changes drastically according to protein supply. After rats were fed a protein-free diet (PF) or a $12 \%$ casein diet for 1 week, their IR and IRS-1 states were analyzed by immunoblotting using various antibodies. PF slightly increased the amount of IR without affecting the state of IR tyrosine phosphorylation. In contrast, PF decreased the amount of IRS-1 and markedly increased phosphorylation of IRS-1 tyrosine residues after insulin injection. Moreover, IRS-1 in PF rats exhibited faster mobility in SDS-PAGE as well as far less phosphorylation of Ser612 and Ser307, indicating hypophosphorylation on its serine residues. Results of additional experiments using energy-restricted (pair-fed) rats and streptozotocin-induced diabetic rats suggest that dietary protein deficiency by itself alters serine phosphorylation of IRS-1, while the up-regulation of tyrosine phosphorylation requires other factors, such as a reduction in basal plasma insulin. The serine dephosphorylation followed by up-regulation of insulin-dependent IRS-1 tyrosine phosphorylation in skeletal muscle of PF rats in vivo is similar to a phenomenon observed in cultured cells under restriction of amino acids in the medium. With these findings, it could be inferred that the reduction of serine phosphorylation contributes to the sensitization of IRS-1 to IR tyrosine kinase under protein malnutrition.
\end{abstract}

Journal of Molecular Endocrinology (2004) 32, 519-531

\section{Introduction}

Low-protein diets ameliorate the symptoms of some diabetic patients, possibly by improving insulin sensitivity and alleviating hyperinsulinemia (Rigalleau et al. 1998). The effectiveness of the low-protein treatment is accentuated if diabetic renal failure is also considered (Aparicio et al. 2001). Using experimental animal models, it has been shown that the source of dietary protein affects energy metabolism by altering insulin action (Lavigne et al. 2000, Ishihara et al. 2003). In addition, dietary protein has been shown to modulate some insulin-dependent processes, such as the regulation of enzymes for gluconeogenesis (Kettelhut et al. 1980, Peret et al. 1981, Rossetti et al. 1989, Iritani et al. 1995, 1996). These observations suggest that protein nutrition influences the signaling pathway of insulin.

Upon activation by insulin, the insulin receptor (IR) binds to various types of substrate proteins, including adapters, docking proteins and enzymes; the family of IR substrate (IRS) proteins constitutes the major group. The IRS family comprises four proteins, IRS-1, IRS-2, IRS-3 and IRS-4 (White 1998, 2002, Saltiel \& Kahn 2001). IRS-1 was the first to be identified and is the best-characterized. It is a $165-185 \mathrm{kDa}$ protein containing abundant 
potential sites for tyrosine phosphorylation and serine/threonine phosphorylation (Sun et al. 1991). This protein contains a pleckstrin homology domain and a phosphotyrosine-binding domain, which together are necessary for its coupling to the activated IR. This coupling activates IRS-1 by phosphorylating its tyrosine residues. The activated IRS-1 recruits and interacts with the Src homology 2 (SH-2) domain-containing proteins, including phosphatidylinositol 3 (PI3) kinase, Grb2 and SH-PTP2 (White 1998, 2002, Saltiel \& Kahn 2001). Other IRSs work in essentially the same manner, although they are distributed differently.

It has recently been shown that amino acids affect serine/threonine phosphorylation and the degradation of IRS proteins in cell culture systems. Serine phosphorylation and the subsequent degradation of IRS-1 by prolonged treatment of 3T3-L1 cells with insulin both depend on the concentrations of amino acids in the culture medium (Takano et al. 2001) and on mTOR, a kinase regulated by amino acids (Hara et al. 1998, Iiboshi et al. 1999). Patti et al. (1998) showed that amino acids inhibit insulin-induced tyrosine phosphorylation of IRS-1 in 3T3-L1, CHO and L6 muscle cells. In addition, Tremblay \& Marette (2001) showed that the excess amino acids enhanced insulin-induced IRS-1 degradation via mTOR/p70 S6 kinase and attenuated insulin-stimulated glucose transport in L6 myotubes. Although a clear link between amino acid availability and insulin signaling components in cultured cells has emerged from these studies, the relevance of this relationship in vivo remains unknown. The substantiation of these phenomena using protein malnutrition models, in which the compositions of plasma amino acids are disturbed, will provide important insights into the pathology, treatment and prevention of type 2 diabetes. Here we made use of an extreme protein malnutrition model, which are rats deprived of dietary protein, and revealed a dietary protein-dependent modulation of the early components of insulin signaling in the muscle. The results indicate that protein malnutrition elevates tyrosine phosphorylation of IRS-1 in response to insulin stimulation. In addition, the level of serine phosphorylation of IRS-1 is drastically reduced in protein-deprived rats, which may account in part for the increased insulin sensitivity of IRS-1. These results are in line with the up-regulation of insulin action in studies using low-protein diets or plant protein-based diets.

\section{Materials and methods}

\section{Materials}

Monoclonal anti-phosphotyrosine antibody (4 G10), polyclonal anti-phospho IRS-1 (Ser307) antibody and polyclonal anti-PI3 kinase p85 antibody were purchased from Upstate Biotechnology (Lake Placid, NY, USA). The polyclonal anti-IRS-1 and anti-IR $\beta$-subunit (IR $\beta$ ) antibodies were purchased from Santa Gruz Biotechnology, Inc. (Santa Cruz, CA, USA). The polyclonal anti-IRS-1 (pS616) phosphoserine-specific antibody was purchased from Biosource International (Camarillo, CA, USA). Bovine insulin and streptozotocin (STZ) were purchased from Sigma Chemical Co. (St Louis, MO, USA). Protein G-Sepharose 4FF and horseradish peroxidase-conjugated secondary antibodies were purchased from Amersham Pharmacia Biotech (Piscataway, NJ, USA). The other chemicals were of reagent grade and were obtained commercially.

\section{Animals and diets}

Male Wistar rats weighing $\sim 130-150 \mathrm{~g}$ were purchased from Charles River Japan, Inc. (Kanagawa, Japan). Rats were kept in a room maintained at $22 \pm 1{ }^{\circ} \mathrm{C}$ with a relative humidity of $60 \%$ and with a cycle of $12 \mathrm{~h}$ light (0800-2000 h) and $12 \mathrm{~h}$ darkness. They were fed a $12 \%$ casein diet $(12 \mathrm{C})$ between 1000 and $1800 \mathrm{~h}$ for the first 3 days and were then divided into two groups of five rats each. One group was fed $12 \mathrm{C} 8 \mathrm{~h}$ per day for 8 days, with free access to water throughout the experiment. The other group was fed a protein-free diet $(\mathrm{PF})$ in the same way. The composition of the $12 \mathrm{C}$ and that of the PF was described previously (Takahashi et al. 1990). On the 8th day, the rats were given their respective diets for $1.5 \mathrm{~h}$ and were then anesthetized with pentobarbital $(50 \mathrm{mg} / \mathrm{kg}$ body weight). After anesthesia was ensured by loss of the pedal reflexes, the abdominal cavity was opened, and $1 \mathrm{ml}$ saline with or without insulin $(1.4 \mathrm{U})$ was injected into the inferior vena cava. The gastrocnemius muscle was removed $2 \mathrm{~min}$ after injection, frozen immediately in liquid 
nitrogen, and stored at $-80{ }^{\circ} \mathrm{C}$ until analysis. In another experiment, two groups of rats were pair-fed as follows. The amount of food consumed by the PF group was monitored each day, and that

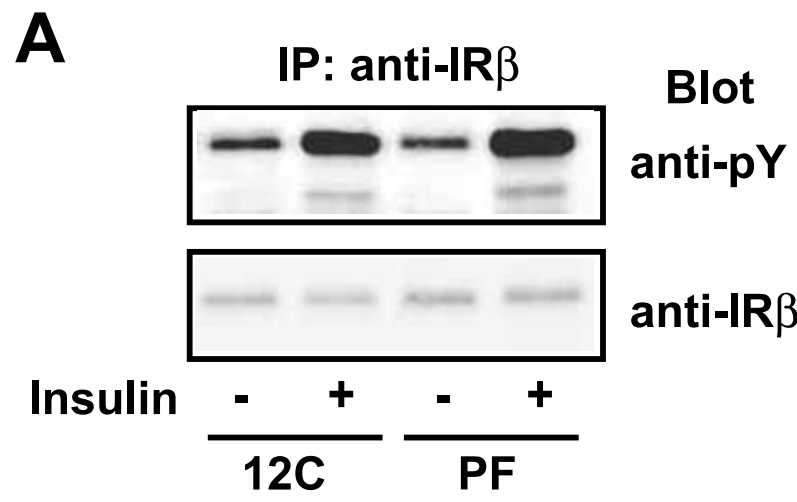

B
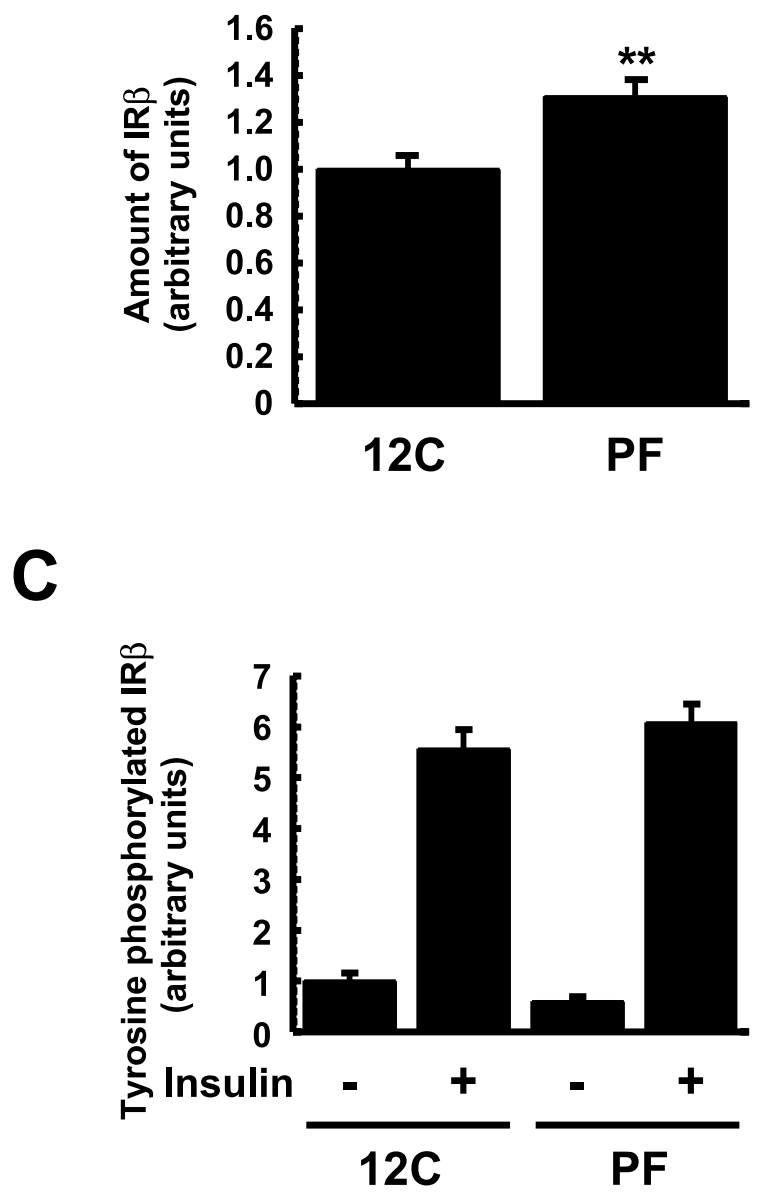

www.endocrinology.org amount was given to the $12 \mathrm{C}$ group on the next day. Accordingly, the insulin injection and tissue sampling of the 12C group were done one day after those of the $\mathrm{PF}$ group.

In addition, rats with impaired insulin secretion were prepared by injecting them with STZ. They were given $12 \mathrm{C}$ between 1000 and $1800 \mathrm{~h}$ for 3 days and on day 4 were injected with STZ (65 mg/body weight, dissolved in $50 \mathrm{mM}$ citrate buffer, $\mathrm{pH} 4 \cdot 5$, and diluted in saline) or saline i.p. at $1000 \mathrm{~h}$ after $16 \mathrm{~h}$ starvation. The development of diabetes was confirmed by analyzing the blood glucose level. Two days after the STZ injection, the rats were divided into two groups according to blood glucose level. They were then given one of the experimental diets for 8 days as described above. To measure plasma glucose level, we collected blood from the tail. In all experiments, to measure the serum insulin level we bled the animals from the carotid artery before killing them. The experimental procedures used in the present study met the guidelines of the Animal Usage Committee of the Faculty of Agriculture, the University of Tokyo.

\section{Measurements of plasma glucose and serum insulin}

The plasma glucose level was determined by a Glucose B-test Wako Kit using the GOD method (Wako Pure Chemical Industries, Osaka, Japan). Serum insulin level was measured by an InsulinEIA Test Kit (Wako).

Figure 1 Effect of protein deprivation on the amount of IR and its tyrosine phosphorylation in rat skeletal muscle. Rats were fed $12 \mathrm{C}$ or PF diet from 1000 to $1800 \mathrm{~h}$ for 7 days. On the 8th day, they were given their respective diets for $1.5 \mathrm{~h}$ and were then anesthetized. During anesthesia, insulin (1.4 $\mathrm{U}$ ) or saline was injected into the inferior vena cava. Two minutes after the injection, the gastrocnemius muscle was excised and quickly frozen. Protein extracts were prepared from the skeletal muscle as described in Materials and methods. (A) The immunoprecipitated IR $\beta$ from the protein extract of the skeletal muscle was analyzed by immunoblotting with antibodies against phosphotyrosine (pY, upper panel) and IR $\beta$ (lower panel). (B) Amount of IR $\beta$. Values shown are the means \pm S.E.M. for five rats. ${ }^{* *} P<0.01$ vs the $12 \mathrm{C}$ group. (C) Tyrosine phosphorylation of IR $\beta$ per the amount of IR $\beta$. Values shown are the means \pm S.E.M. for five rats. 


\section{Preparation of extracts from muscle}

The samples for immunoblotting were prepared as described previously (Ito et al. 1997). The frozen tissues were ground into a fine powder with a mortar and then homogenized with a homogenizer at $4{ }^{\circ} \mathrm{C}$ in seven times the tissue weight of a homogenizing buffer $(50 \mathrm{mM}$ Hepes- $\mathrm{NaOH}$, pH

A

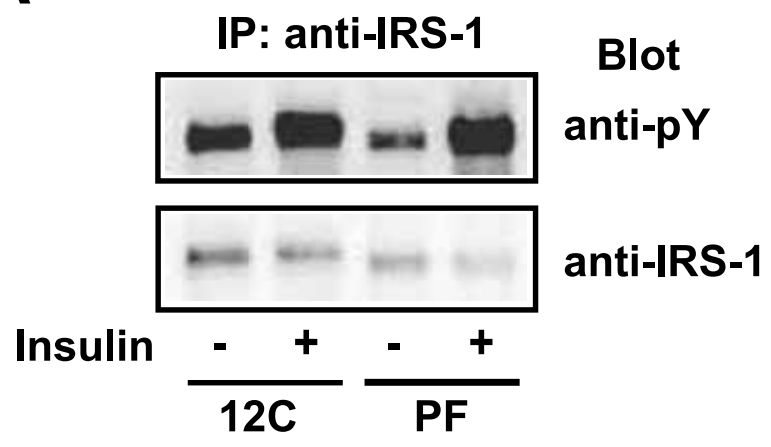

B
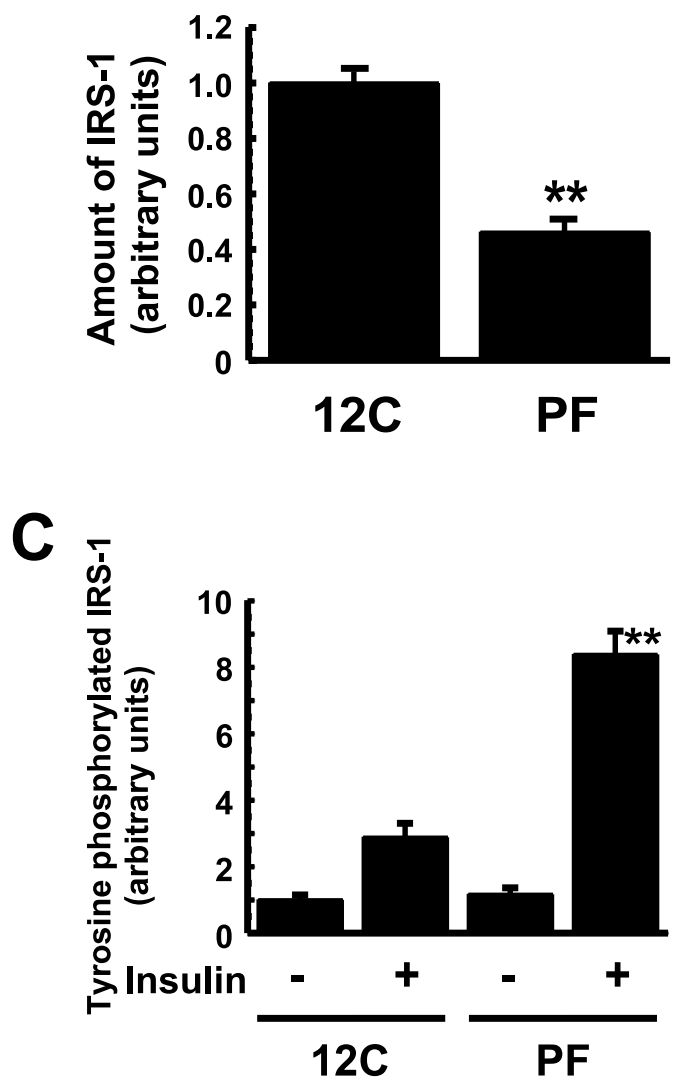

Journal of Molecular Endocrinology (2004) 32, 519-531
7·6, $10 \mathrm{mM}$ sodium orthovanadate, $10 \mathrm{mM}$ sodium pyrophosphate, $100 \mathrm{mM}$ sodium fluoride, $2 \mathrm{mM}$ phenylmethylsulfonyl fluoride, $100 \mathrm{kIU} / \mathrm{ml}$ aprotinin, $2 \mathrm{mM}$ EDTA, and 2\% Triton X-100). All extracts were centrifuged at $100000 \boldsymbol{g}$ for $1 \mathrm{~h}$ at $4{ }^{\circ} \mathrm{C}$, and the supernatants were collected for further analysis. The protein content in the supernatants was determined using a Bio-Rad Protein Assay Kit (Bio-Rad, Hercules, CA, USA), according to the method of Bradford (1976).

\section{Immunoprecipitation and immunoblot analysis}

The extracted protein $(5 \mathrm{mg})$ was incubated with an anti-IR $\beta$ antibody $(4 \mu \mathrm{g})$ or an anti-IRS- 1 antibody $(4 \mu \mathrm{g})$ at $4{ }^{\circ} \mathrm{C}$ overnight, and was incubated for another $3 \mathrm{~h}$ after $30 \mu \mathrm{l}$ protein G-Sepharose $4 \mathrm{FF}$ $(50 \% \mathrm{v} / \mathrm{v})$ were added. The immune complexes were washed three times with the homogenizing buffer at $4{ }^{\circ} \mathrm{C}$, suspended in Laemmli's sample buffer, and boiled for $5 \mathrm{~min}$. An equal volume of each sample was resolved by $8 \%$ SDS-PAGE and transferred to a nitrocellulose membrane (Hybond ECL; Amersham) using a Trans-Blot SD Cell (Bio-Rad). After transblotting, the membranes were rinsed once with a rinsing buffer $(10 \mathrm{mM}$ Tris-HCl, pH 7.2, $50 \mathrm{mM} \mathrm{NaCl}$ and $1 \mathrm{mM}$ EDTA), and blocked with a blocking buffer (rinsing buffer containing $3 \% \mathrm{BSA}$ ) at $4{ }^{\circ} \mathrm{C}$ overnight. The membranes were then incubated with appropriate antibodies diluted in the blocking buffer at room temperature for $2 \mathrm{~h}$, and were washed five times with TBS-T (20 mM Tris-HCl, pH 7·6, $137 \mathrm{mM}$ $\mathrm{NaCl}, 1 \mathrm{mM}$ EDTA and $0 \cdot 1 \%$ Tween 20). The membrane was then incubated with horseradish peroxidase-conjugated anti-rabbit or anti-mouse

Figure 2 Effect of protein deprivation on the amount of IRS-1 and its tyrosine phosphorylation in rat skeletal muscle. Rats were fed $12 \mathrm{C}$ or PF diet for 7 days and treated with insulin, as described in the legend to Fig. 1. The gastrocnemius muscle was dissected 2 min after insulin injection. (A) The immunoprecipitated IRS-1 from the protein extract of rat skeletal muscle was analyzed by immunoblotting with antibodies against phosphotyrosine (pY, upper panel) and IRS-1 (lower panel). (B) Amount of IRS-1. Values shown are the means \pm S.E.M. for five rats. ${ }^{* \star} P<0.01$ vs the $12 \mathrm{C}$ group injected with insulin. (C) Tyrosine phosphorylation of IRS-1 per the amount of IRS-1. Values shown are the means \pm S.E.M. for five rats. ${ }^{* \star} P<0.01$ vs the $12 \mathrm{C}$ group injected with insulin. 
IgG diluted in TBS-T for $1 \mathrm{~h}$, and washed again as described above. The bands of immunoreactive protein were detected with the ECL kit (Amersham) and quantified using a cooled CCD camera system, LAS-1000 plus (Fuji Film Co., Kanagawa, Japan).

\section{Statistical analyses}

All values are expressed as the means \pm S.E.M. The results of plasma glucose and serum insulin level in the STZ study were analyzed statistically using the Duncan's multiple range test. The Student's $t$-test was performed when the comparisons were between two groups, mainly between insulininjected rats fed on $12 \mathrm{C}$ and those fed on PF. Differences were considered to be statistically significant at $P<0 \cdot 05$.

\section{Results}

\section{Protein deprivation does not affect insulin-induced tyrosine phosphorylation of IR in rat skeletal muscle}

We first examined whether or not protein deprivation influences the insulin-induced tyrosine phosphorylation of IR by immunoblotting. Our preliminary experiments showed that the tyrosine phosphorylation of the IR in muscle peaked at 2 min after insulin was injected into the inferior vena cava (data not shown). The state of each component of IR signaling was analyzed in all experiments described hereafter.

The amount of IR was slightly but significantly higher in the PF rats than in the $12 \mathrm{C}$ rats (Fig. 1A, an immunoblot using anti-IR $\beta$ antibody, and Fig. 1B). Irrespectively of the injection of insulin, the postprandial tyrosine phosphorylation of IR was lower in the $\mathrm{PF}$ rats than in the $12 \mathrm{C}$ rats (Fig. 1A, an immunoblot using anti-phosphotyrosine antibody, and Fig. 1C, first and third bars), which might reflect the lower serum insulin level of $\mathrm{PF}$ rats (shown below). On the other hand, insulininduced tyrosine phosphorylation of IR did not differ between the two dietary groups (second and fourth bars of Fig. 1C). Protein deprivation thus has only a limited effect on the insulin responsiveness of IR in skeletal muscle.

\section{Protein deprivation augments insulin-induced tyrosine phosphorylation of IRS-1 through the reduction of its serine phosphorylation in skeletal muscle}

We next examined whether or not protein deprivation affected the insulin-stimulated phosphorylation of IRS-1 in skeletal muscle. The amount of IRS-1 in the skeletal muscle of the PF group was reduced to $50 \%$ of that of the $12 \mathrm{C}$ group (Fig. 2A, an immunoblot using anti-IRS-1 antibody, and Fig. 2B). On the other hand, the level of tyrosine phosphorylation of IRS-1 in response to insulin stimulation was higher in the $\mathrm{PF}$ rats than in the $12 \mathrm{C}$ rats (Fig. 2A, an immunoblot using anti-phosphotyrosine antibody). Together these changes demonstrate that the insulin-induced tyrosine phosphorylation of IRS-1 was three times higher in the $\mathrm{PF}$ than in the $12 \mathrm{C}$ rats, when normalized by the amount of IRS-1 (Fig. 2G). In other words, three times as many tyrosine residues in each IRS-1 molecule became phosphorylated in response to insulin in the $\mathrm{PF}$ group than in the $12 \mathrm{C}$ group. This suggests that the sensitivity of IRS-1 to IR kinase is up-regulated in the PF rats.

It is noteworthy that the migration patterns of IRS-1 differ between the groups (Fig. 2A, an immunoblot using anti-IRS-1 antibody), in that IRS- 1 in the muscle of the PF rats migrated faster than that of the $12 \mathrm{C}$ rats. This apparent reduction of molecular mass, which was seen even in the unstimulated state, suggests an alteration of some modification other than tyrosine phosphorylation. As it is known that tens of serine/threonine residues in IRS-1 are subject to phosphorylation (Sun et al. 1991), we then explored whether or not protein nutrition affects the serine phosphorylation of IRS-1. To this end, we investigated two of the known residues of serine phosphorylation, Ser612 (Mothe \& Van Obberghen 1996, De Fea et al. 1997a) and Ser307 (Aguirre et al. 2000, 2002, Rui et al. 2001) using respective antibodies specific to phosphorylated serines of these positions. As shown in Fig. 3, the phosphorylation states of Ser612 and Ser307 differed dramatically between the two dietary groups. Thus, the faster migration of IRS-1 in the $\mathrm{PF}$ rats is probably attributable to the reduced serine (and possibly also threonine) phosphorylation of this molecule.

These results suggest that the reduction of serine phosphorylation in the state of protein deprivation 


\section{IP: anti-IRS-1}
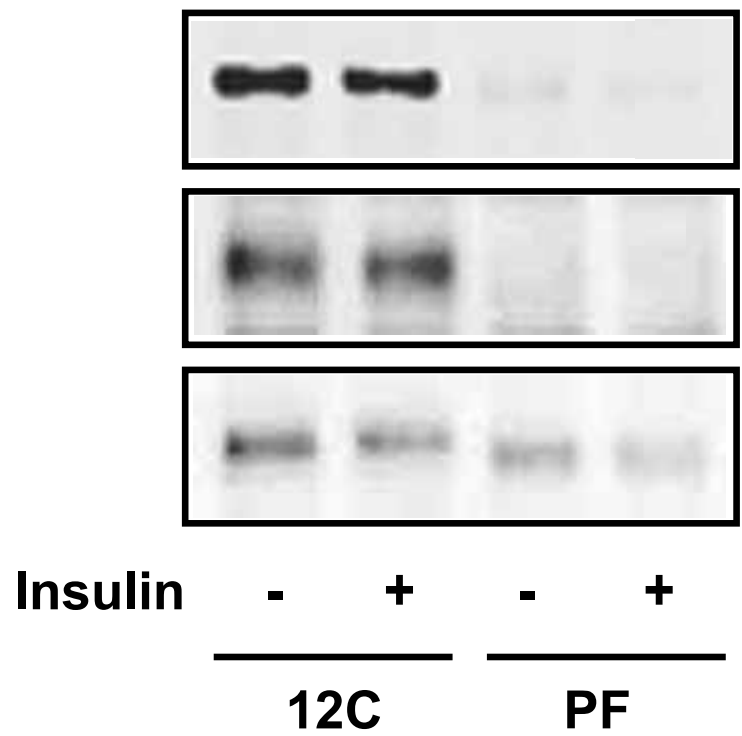

\section{Blot}

\section{anti-pSer612}

IRS-1

\section{anti-pSer307 \\ IRS-1}

\section{anti-IRS-1}

Figure 3 Effect of protein deprivation on Ser612 phosphorylation of IRS-1 in rat skeletal muscle. Rats were fed $12 \mathrm{C}$ or PF diet for 7 days and treated with insulin, as described in the legend to Fig. 1. The immunoprecipitated IRS-1 from the protein extract of rat skeletal muscle was analyzed by immunoblotting with antibodies against phosphorylated Ser612 of IRS-1 (top panel), phosphorylated Ser307 of IRS-1 (middle panel), and IRS-1 (bottom panel).

enhances insulin-induced tyrosine phosphorylation of IRS-1. We also examined IRS-1 mRNA levels in the muscle. The results showed no difference between the diets (data not shown), indicating that the dietary protein condition does not affect IRS-1 gene transcription.

\section{Protein deprivation increases insulin-dependent association of p85 regulatory subunit of $\mathrm{PI} 3$ kinase in rat skeletal muscle}

The next attempt was made to explore whether the increased insulin-induced tyrosine phosphorylation of IRS-1 by protein deprivation is reflected in the downstream signaling of insulin. The level of the association of the p85 regulatory subunit of PI3 kinase with IRS-1 was determined in the muscle. As shown in Fig. 4, the amount of IRS-1-associated p85 was significantly higher in PF than in $12 \mathrm{C}$ rats, despite the reduced amount of IRS-1 in PF rats. This result indicates that the up-regulation of IRS-1 activity by protein deprivation leads to amplification of the downstream insulin signaling.

\section{Protein malnutrition reduces serine phosphorylation of IRS-1 independently of changes in food intake or plasma insulin}

As shown in Table 1, deprivation of dietary protein resulted in mild reductions in food intake and plasma insulin. It is thus highly possible that these changes caused the alterations in the serine phosphorylation and insulin responsiveness of IRS-1 tyrosine phosphorylation. To distinguish the direct effects of dietary protein from the effects of food intake and basal insulin level, we performed two additional experiments: one under a pairfeeding condition and the other in an STZ-induced insulin deficiency.

In the experiment shown in Fig. 5, the amount of food given to rats in the $12 \mathrm{C}$ group was the amount that the PF group had consumed on the previous day. Even in this eucaloric condition, there was a striking difference in Ser612 phosphorylation 

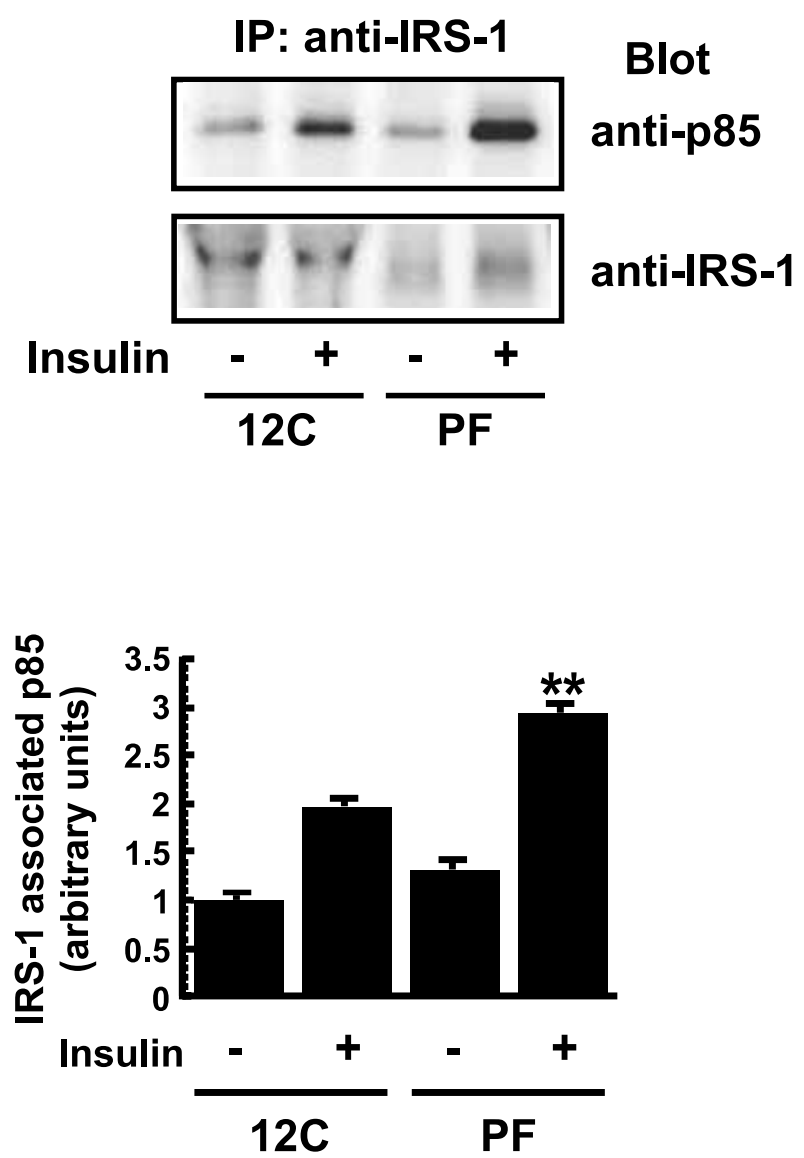

Figure 4 Effect of protein deprivation on the amount of IRS-1-associated p85 regulatory subunit of PI3 kinase in rat skeletal muscle. Rats were fed $12 \mathrm{C}$ or PF diet for 7 days and treated with insulin, as described in the legend to Fig. 1. The gastrocnemius muscle was dissected 2 min after insulin injection. (A) The immunoprecipitated IRS-1 from the protein extract of rat skeletal muscle was analyzed by immunoblotting with antibodies against p85 regulatory subunit of PI3 kinase (p85, upper panel) and IRS-1 (lower panel). (B) Amount of IRS-1-associated p85 regulatory subunit of PI3 kinase. Values shown are the means \pm S.E.M. for five rats. ${ }^{* *} P<0.01$ vs the $12 \mathrm{C}$ group injected with insulin. between the dietary groups (Fig. 5A). The reduction of IRS-1 by PF was evident although less prominent than in the freely feeding group (Fig. 5B and $\mathrm{C}, 20 \%$ decrease). As in Fig. 5B and D, the insulin-induced tyrosine phosphorylation of IRS-1 was significantly higher in $\mathrm{PF}$ than in $12 \mathrm{C}$ rats, but the difference was again blunted (30\% increase). Similarly, in a model of mild insulin deficiency (Table 2), PF rats consistently retained the activity to dephosphorylate Ser612, but the effect on the amount and tyrosine phosphorylation of IRS-1 was weakened (Fig. 6). It is known from cell culture studies that hyperglycemia itself increase serine phosphorylation of IRS-1 (Nakajima et al. 2000). This result shows that dietary protein is effective even in a hyperglycemic condition. The results of Figs 5 and 6 show that dietary protein deficiency alters Ser612 phosphorylation on its own and that it works cooperatively with energy and insulin status to regulate the amount and tyrosine phosphorylation of IRS-1.

\section{Discussion}

Previous studies have indicated that the intake of a high-protein diet is related to increased gluconeogenesis and impaired hepatic insulin sensitivity in rats (Kettelhut et al. 1980, Peret et al. 1981, Rossetti et al. 1989). However, little information is available on how dietary protein affects insulin sensitivity in peripheral tissues. Previously, Reis et al. (1997) reported that insulin-induced tyrosine phosphorylation of IR and of IRS-1 was increased in liver and skeletal muscle of rats fed a low-protein diet. In cell culture studies, amino acids are shown to inhibit insulin-induced tyrosine phosphorylation of IRS-1 (Patti et al. 1998) and to enhance insulin-induced

Table 1 Metabolic parameters in 12C- and PF-fed rats. The values are the means \pm S.E.M. for five rats

\begin{tabular}{|c|c|c|c|c|c|}
\hline \multicolumn{3}{|l|}{ Ad libitum } & \multicolumn{3}{|c|}{ Pair-feeding } \\
\hline $\begin{array}{l}\text { Food intake } \\
\text { (g/day) }\end{array}$ & $\begin{array}{l}\text { Body weight } \\
\text { (g) }\end{array}$ & $\begin{array}{l}\text { Serum insulin } \\
(\mathrm{mU} / \mathrm{ml})\end{array}$ & $\begin{array}{l}\text { Food intake } \\
\text { (g/day) }\end{array}$ & $\begin{array}{l}\text { Body weight } \\
\text { (g) }\end{array}$ & $\begin{array}{l}\text { Serum insulin } \\
(\mathrm{mU} / \mathrm{ml})\end{array}$ \\
\hline $\begin{array}{c}18 \cdot 0 \pm 0 \cdot 2 \\
9 \cdot 7 \pm 0 \cdot 3^{\star *}\end{array}$ & $\begin{array}{l}215 \cdot 6 \pm 2 \cdot 4 \\
141 \cdot 5 \pm 1 \cdot 5^{\star \star}\end{array}$ & $\begin{array}{l}58 \cdot 0 \pm 9 \cdot 9 \\
35 \cdot 1 \pm 8 \cdot 1\end{array}$ & $\begin{array}{l}10 \cdot 8 \pm 0 \cdot 2 \\
10 \cdot 8 \pm 0 \cdot 2\end{array}$ & $\begin{array}{l}180 \cdot 3 \pm 2 \cdot 2 \\
148 \cdot 4 \pm 1 \cdot 6^{\star *}\end{array}$ & $\begin{array}{l}22 \cdot 5 \pm 5 \cdot 8 \\
24 \cdot 7 \pm 4 \cdot 4\end{array}$ \\
\hline
\end{tabular}

${ }^{\star *} P<0.01$ vs $12 \mathrm{C}$-fed groups.

www.endocrinology.org 
A

B

IP: anti-IRS-1

IB: anti-pSer612 IRS-1

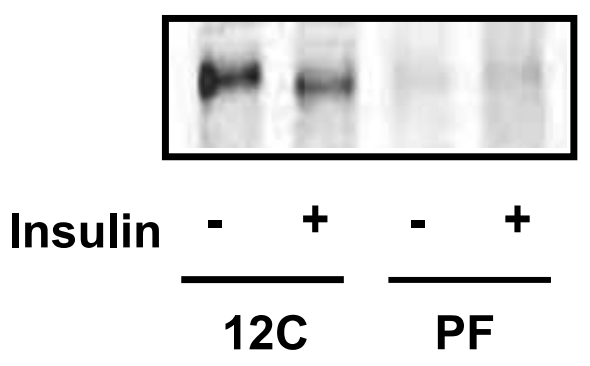

C

\section{IP: anti-IRS-1}

anti-pY

anti-IRS-1

\section{Blot}
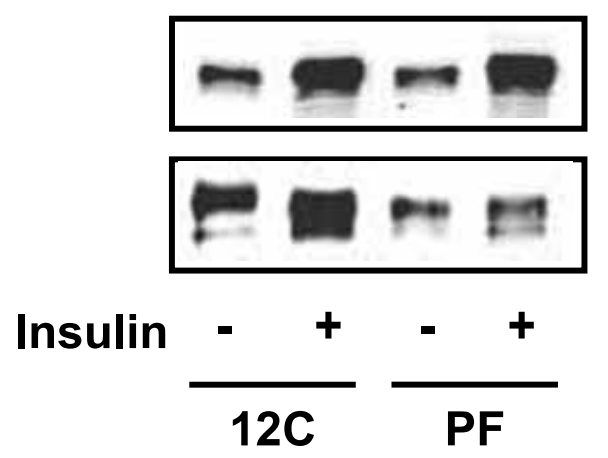
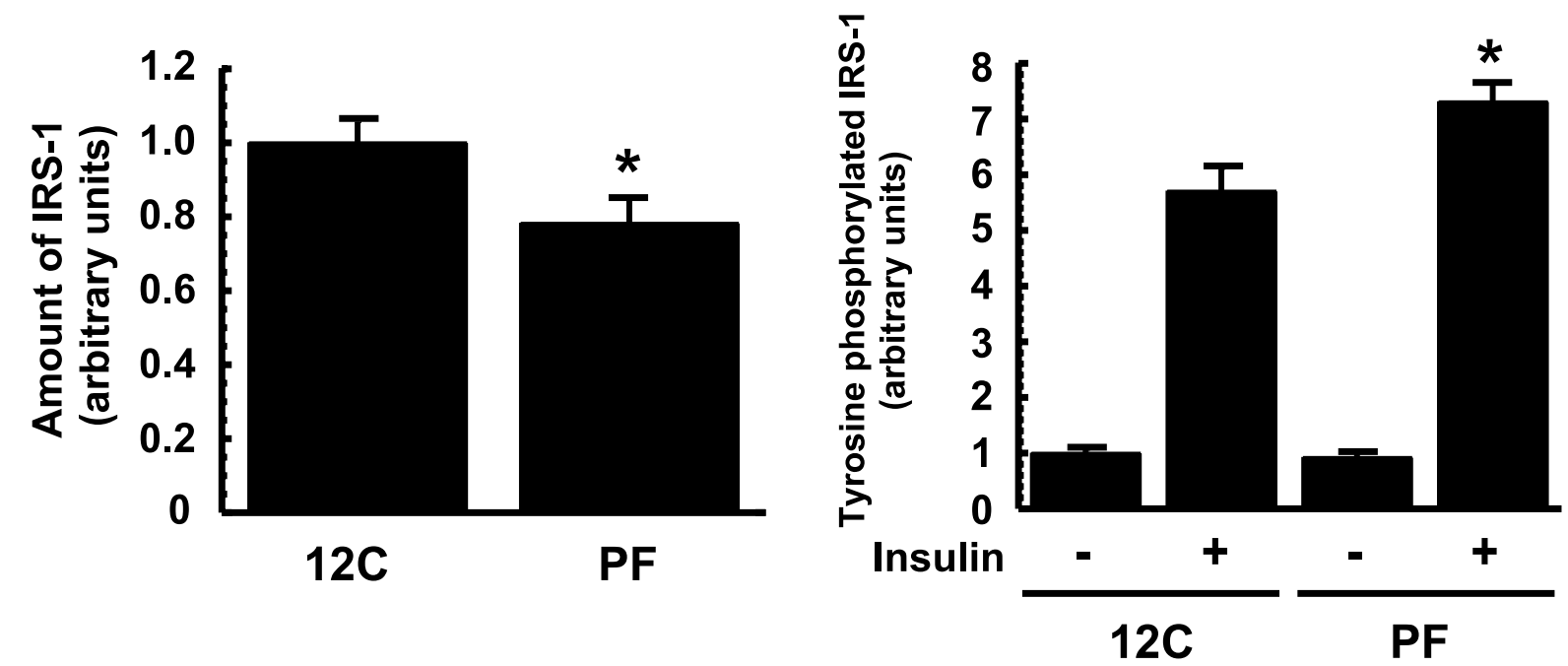

Figure 5 Effects of restricted feeding on the dietary protein-dependent changes in the amount, tyrosine phosphorylation, and Ser612 phosphorylation of IRS-1 in rat skeletal muscle. Rats were fed a 12C or PF diet from 1000 to $1800 \mathrm{~h}$ for 7 days. The amount consumed by the PF rats was monitored daily, the mean of which was supplied to each $12 \mathrm{C}$ rat on the next day (pair-feeding). On the 8th day, the rats in both groups were treated with insulin, as described in the legend to Fig. 1. The muscle was dissected 2 min after insulin injection. (A) The immunoprecipitated IRS-1 from the protein extract of the muscle was analyzed by immunoblotting with antibodies against phosphorylated Ser612 (pSer612) of IRS-1. (B) The immunoprecipitated IRS-1 from the protein extract of the muscle was analyzed by immunoblotting with antibodies against IRS-1 and phosphotyrosine (pY). (C) Amount of IRS-1. The values are means \pm S.E.M. for five rats. ${ }^{*} P<0.05$ vs the $12 \mathrm{C}$ group. (D) Tyrosine phosphorylation of IRS-1 per the amount of IRS-1. Values shown are the means \pm S.E.M. for five rats. ${ }^{*} P<0.05$ vs the $12 \mathrm{C}$ group injected with insulin. 
Table 2 Plasma glucose and insulin levels: effect of STZ treatment

\begin{tabular}{|c|c|c|c|c|}
\hline & $\begin{array}{l}\text { Control-12C } \\
(n=10)\end{array}$ & $\begin{array}{l}\text { Control-PF } \\
(n=12)\end{array}$ & $\begin{array}{l}\text { STZ-12C } \\
(n=15)\end{array}$ & $\begin{array}{l}\text { STZ-PF } \\
(n=15)\end{array}$ \\
\hline \multicolumn{5}{|l|}{ Plasma glucose $(\mathrm{mg} / \mathrm{dl})$} \\
\hline After 2 days of STZ injection & $155 \cdot 9 \pm 2 \cdot 4^{\mathrm{a}}$ & $160 \cdot 4 \pm 5 \cdot 1^{\mathrm{a}}$ & $570 \cdot 0 \pm 28 \cdot 4^{\mathrm{b}}$ & $619 \cdot 5 \pm 43 \cdot 7^{b}$ \\
\hline At killing & $160 \cdot 7 \pm 6 \cdot 1^{a}$ & $163 \cdot 8 \pm 5 \cdot 7^{\mathrm{a}}$ & $612 \cdot 7 \pm 36 \cdot 1^{\mathrm{b}}$ & $407 \cdot 2 \pm 108 \cdot 9^{a b}$ \\
\hline Serum insulin (mU/ml) & $44 \cdot 1 \pm 5 \cdot 9^{a}$ & $19 \cdot 5 \pm 3 \cdot 0^{b}$ & $11 \cdot 5 \pm 2 \cdot 2^{\mathrm{b}}$ & $13 \cdot 2 \pm 2 \cdot 6^{\mathrm{b}}$ \\
\hline
\end{tabular}

serine/threonine phosphorylation and degradation simultaneously (Takano et al. 2001). Moreover, it has been shown that the excess of amino acids attenuates insulin-stimulated glucose transport in vitro, while amino acid deficiency enhances it (Takano et al. 2001, Tremblay \& Marette 2001). Thus, it is highly probable that the early steps of insulin signaling are up-regulated by restricted supplies of amino acids; the relevance and the underlying mechanisms, however, remain unknown, especially in vivo.

This study is the first to report that protein malnutrition reduces serine phosphorylation of IRS-1 in rat skeletal muscle. The initial intriguing finding was the obvious difference between the 12C and PF groups in the migration pattern of IRS-1 protein in SDS-PAGE. A following assay using the antibodies recognizing phosphoserine 612 and 307 of IRS-1 linked the shift in IRS-1 migration to a drastic change in serine phosphorylation (Fig. 3). Additional experiments using pair-fed and STZtreated rats showed that the dietary protein condition by itself affected the Ser612 phosphorylation of IRS-1 (Figs 5A and 6A). In this study, we examined only a couple of the serine residues in IRS-1, but the apparent differences in the migration of IRS-1 proteins implies that protein malnutrition likely alters the phosphorylation states of many other serine residues (and probably of threonine residues also).

Increased serine/threonine phosphorylation of IRS-1 has been recognized as a major cause of insulin resistance and is induced by a variety of factors, such as tumor necrosis factor- $\alpha$, insulin, platelet-derived growth factor, protein kinase $\mathrm{C}$ activators, and inhibition of protein phosphatase $\mathrm{A}$ with okadaic acid (Tanti et al. 1994, Kanety et al. 1995, Hotamisligil et al. 1996, De Fea et al. 1997a,b, Li et al. 1999, Sun et al. 1999, Liu et al. 2001,
Pederson et al. 2001, Ravichandran et al. 2001, Hartley \& Cooper 2002). In each of these events, several serine residues of IRS-1 have been identified as the target, and the molecular mechanism leading to the alteration of serine phosphorylation is being elucidated in cell culture systems. Examples of such pathways include Ser612 phosphorylation of IRS-1 through MAP kinase activation (De Fea et al. 1997b) and Ser307 phosphorylation through JNK (Aguirre et al. 2000, 2002). We then analyzed the state of ERK phosphorylation by immunoblotting, but found no difference between the $12 \mathrm{C}$ and $\mathrm{PF}$ rats in terms of ERK 2 phosphorylation and total ERKs phosphorylation (data not shown). JNK1/2 phosphorylation did not change, either (Y Ohne, Y Toyoshima \& H Kato, unpublished observations). Considering the complexity of the whole-body system compared with cultured cells, additional parameters, such as other endocrine factors, may need to be taken into account. The candidates may include insulin-like growth factor (IGF-I), since IGF-I and its binding proteins are highly responsive to protein nutrition (Takahashi et al. 1990, Takenaka et al. 1993) and the signaling pathway of the IGF-I receptor shares most of its components with the IR.

In a study using L6 myotubes, Tremblay \& Marette (2001) showed that the insulin-induced degradation of IRS-1, a process demanding amino acids, depends on the mTOR/p70 S6 kinase pathway but not on MAP kinase. In contrast to our present results, they observed that amino acids did not affect Ser612 phosphorylation, which coincided with the lack of a role for MAP kinase in the degradation and Ser612 phosphorylation of IRS-1. Another discrepancy between their results and ours is that the supply of dietary protein in vivo increases the amount of IRS-1, while the addition of amino acid in culture medium decreases it, although both 
treatments increase its serine phosphorylation. These differences could be attributed to the systems used, namely in vivo muscle vs cultured cells. Furthermore, tissue specificity needs to be carefully taken into account. In fact, we have already observed that IRS-1 and the related molecules in liver respond very differently to protein malnutrition (Y Toyoshima, Y Ohne, S-I Takahashi, $\mathrm{T}$ Noguchi and $\mathrm{H}$ Kato unpublished observations).

In addition to the study of Tremblay \& Marette (2001), Takano et al. (2001) suggested that mTOR

A

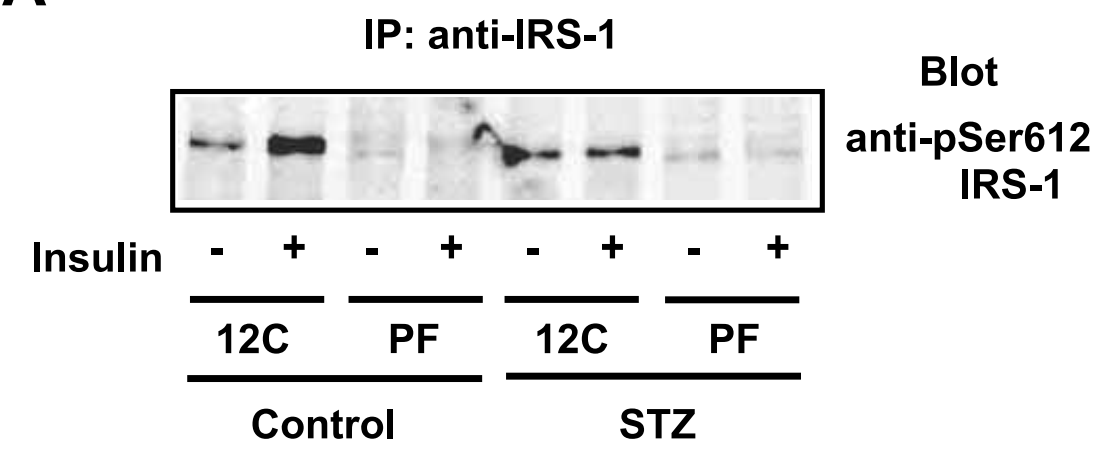

B

IP: anti-IRS-1

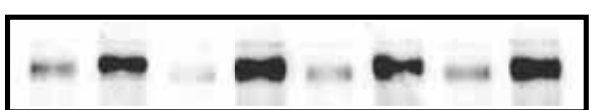

Blot

anti-pY

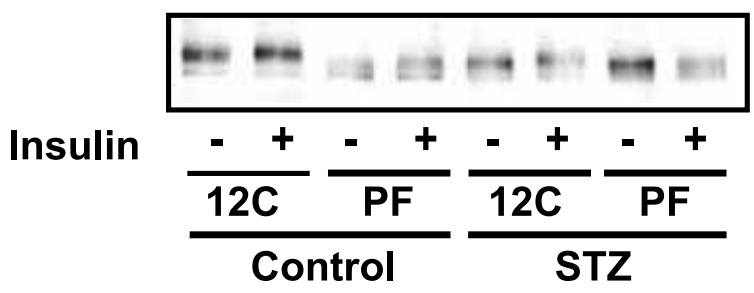

anti-IRS-1

C

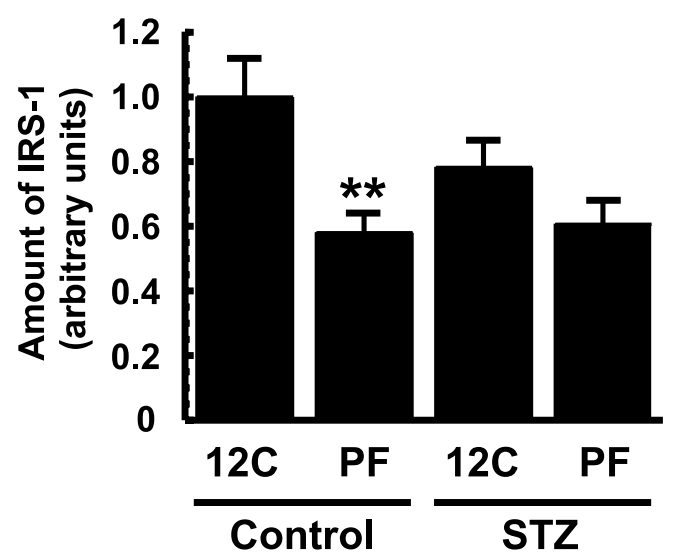

D

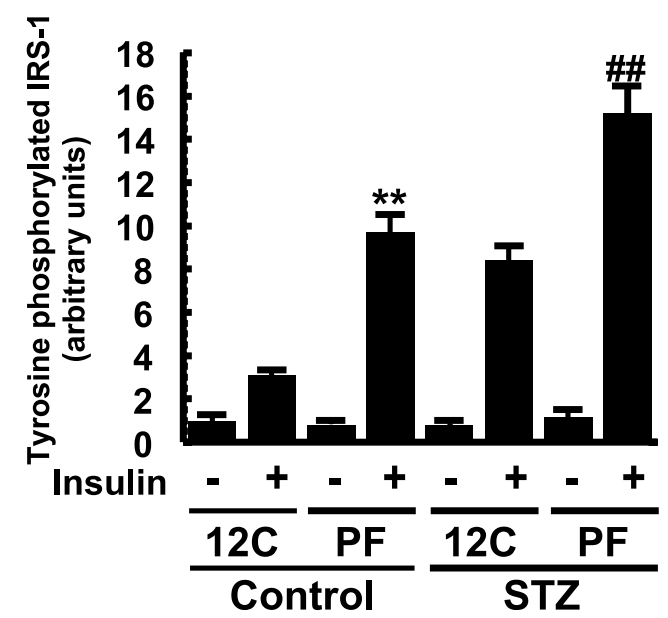


mainly regulated the signals of amino acids in insulin-induced IRS-1 serine phosphorylation and degradation in 3T3-L1 cells. It has been shown that mTOR acts as a sensor for amino acids and balancing the availability of nutrients (Hara et al. 1998, Iiboshi et al. 1999). The translational regulators p70 S6 kinase and 4E-BPI, which are regulated by mTOR (Hara et al. 1998), are also phosphorylated in an amino acid-dependent manner. Yoshizawa et al. $(1998,1999)$ showed that 4E-BP1 and p70 S6 kinase phosphorylation was increased in rat skeletal muscle by refeeding a $20 \%$ casein diet after $18 \mathrm{~h}$ starvation, but not by refeeding a protein-free diet, although the plasma insulin level was the same between both diet groups. Considering these things, mTOR may play a major role in regulating the serine phosphorylation of IRS-1. Administration of an mTOR inhibitor in vivo, for instance, will help in elucidating the role of this kinase in dietary protein-induced alteration of IRS-1.

The present study also addressed the effect of protein nutrition on insulin-induced tyrosine phosphorylation of IRS-1, which is known to be negatively regulated by its serine phosphorylation in cell cultures (Tanti et al. 1994, Kanety et al. 1995, Hotamisligil et al. 1996, De Fea et al. 1997a,b, Li et al. 1999, Sun et al. 1999, Aguirre et al. 2000, 2002, Liu et al. 2001, Pederson et al. 2001, Ravichandran et al. 2001, Rui et al. 2001, Takano et al. 2001, Hartley \& Cooper 2002, Tremblay \& Marrette 2001). Tyrosine phosphorylation after insulin stimulation was significantly higher in the $\mathrm{PF}$ group than in the $12 \mathrm{C}$ group (Fig. 2). In addition, the enhancement by PF of the insulininduced tyrosine phosphorylation of IRS-1 intensifies downstream signaling, as manifested by the increased association of p85 regulatory subunit of PI3 kinase with IRS-1 (Fig. 4). Such changes are likely to result in an enhancement of a variety of actions of insulin. In fact, it seems to be true at least in the case of glucose uptake; the muscle taken from the $\mathrm{PF}$ rats responded better to insulin when 2-deoxyglucose uptake was measured (data not shown). The sensitization of IRS-1 to IR kinase does not seem to be caused by alteration of the IR, since protein nutrition did not affect IR's tyrosine phosphorylation (Fig. 1C). Rather, the sensitization is more reasonably associated with the serine dephosphorylation of IRS-1. This association fits well with the previous observations in cell cultures, but seems to be less tight under situations involving eucaloric food restriction or insulin deficiency (Figs 5 and 6). In these cases, the effect of PF on the sensitization of IRS-1 was attenuated, in contrast to its consistent effect on serine dephosphorylation. Thus, not only the serine phosphorylation but other factors too should play cooperative roles in the up-regulation of insulin-induced tyrosine phosphorylation in the protein malnutritional state. This hypothesis is supported by a previous report that moderate caloric restriction increased insulinstimulated tyrosine phosphorylation of IR and of IRS-1 in rat skeletal muscle (Dean \& Cartee 2000). The reduced effect of protein malnutrition on tyrosine phosphorylation may be explained another way. That is, no ideal model is available that can discriminate between the effects of protein nutrition and those of energy-insulin states. In the present study, the $12 \mathrm{C}$ rats in Figs 5 and 6 are in some degree of protein malnutrition, because (i) the pair-fed 12C group has a lower protein intake than required and (ii) the STZ-treated group is in a state of reduced utilization of amino acid. Together, these factors could be responsible for the blunted effect of PF diet treatment. Another result of our ongoing study - that diets with amino acid imbalances similarly modify IRS-1 without signifi-

Figure 6 Effects of hypoinsulinemia on the dietary protein-dependent changes in the amount, tyrosine phosphorylation, and Ser612 phosphorylation of IRS-1 in rat skeletal muscle. Rats were fed 12C diet from 1000 to $1800 \mathrm{~h}$ for 3 days, and STZ (65 mg/body weight) or saline was injected i.p. on the 4th day. Two days after the STZ injection, the control and STZ-treated rats were fed a $12 \mathrm{C}$ or PF diet for 7 days and treated with insulin, as described in the legend to Fig. 1. The muscle was dissected 2 min after insulin injection. (A) The immunoprecipitated IRS-1 from the protein extract of the muscle was analyzed by immunoblotting with antibodies against phosphorylated Ser612 (pSer612) of IRS-1. (B) The immunoprecipitated IRS-1 from the protein extract of the muscle was analyzed by immunoblotting with antibodies against IRS-1 and phosphotyrosine (pY). (C) Amount of IRS-1. The values are means \pm S.E.M. for five control rats and seven STZ-treated rats. ${ }^{* \star} P<0.01$ vs the $12 \mathrm{C}$ group of control rats. (D) Tyrosine phosphorylation of IRS-1 per the amount of IRS-1. The values are the means \pm S.E.M. for five control rats and seven STZ-treated rats. ${ }^{* *} P<0.01$ vs the $12 \mathrm{C}$ group injected with insulin of control rats. \#\#P<0.01 vs the $12 \mathrm{C}$ group injected with insulin of STZ-treated rats. 
cantly changing plasma insulin (Y Ohne, Y Toyoshima \& H Kato, unpublished observations) further supports the importance of protein nutrition on insulin signaling. A series of experiments under various conditions will help elucidate the precise mechanism of the in vivo modification of IRS-1 activity.

In conclusion, this study revealed that dietary protein is a very strong regulator of serine phosphorylation of IRS-1 in muscle. This change is accompanied by an increased sensitivity of IRS-1 to insulin; this increase may, in turn, contribute to elevated insulin responsiveness by manipulations of dietary protein.

\section{Acknowledgements}

The authors thank Dr Derek LeRoith (National Institutes of Health, USA) for his critical reading of the manuscript and helpful comments. This work was supported by Grant-in-Aid for Scientific Research (No. 12460054 and 15380090) to H K from the Japan Society for the Promotion of Science.

\section{References}

Aguirre V, Uchida T, Yenush L, Davis R \& White MF 2000 The c-Jun $\mathrm{NH}_{2}$-terminal kinase promotes insulin resistance during association with insulin receptor substrate- 1 and phosphorylation of Ser307. Fournal of Biological Chemistry 275 9047-9054.

Aguirre V, Werner ED, Giraud J, Lee YH, Shoelson SE \& White MF 2002 Phosphorylation of Ser 307 in IRS-1 blocks interactions with the insulin receptor and inhibits insulin action. Fournal of Biological Chemistry 277 1531-1537.

Aparicio M, Chauveau P \& Combe C 2001 Are supplemented low-protein diets nutritionally safe? American Fournal of Kidney Diseases 37 S71-S76.

Bradford MM 1976 A rapid and sensitive method for the quantitation of microgram quantities of protein utilizing the principle of protein-dye binding. Analytical Biochemistry 72 248-254.

Dean DJ \& Cartee GD 2000 Calorie restriction increases insulin-stimulated tyrosine phosphorylation of insulin receptor and insulin receptor substrate-1 in rat skeletal muscle. Acta Physiologica Scandinavica 169 133-139.

De Fea K \& Roth RA $1997 a$ Protein kinase C modulation of insulin receptor substrate-1 tyrosine phosphorylation requires serine 612 . Biochemistry 36 12939-12947.

De Fea K \& Roth RA $1997 b$ Modulation of insulin receptor substrate-1 tyrosine phosphorylation and function by mitogen-activated protein kinase. Fournal of Biological Chemistry 272 31400-31406.

Hara K, Yonezawa K, Weng Q-P, Kozlowski MT, Belham C \& Avruch J 1998 Amino acid sufficiency and mTOR regulate p70 S6 kinase and eIF-4E BP1 through a common effector mechanism. Journal of Biological 273 14484-14494.
Hartley D \& Cooper GM 2002 Role of mTOR in the degradation of IRS-1: regulation of PP2A activity. Foumal of Cellular Biochemistry $85304-314$

Hotamisligil GS, Peraldi P, Budavari A, Ellis R, White MF \& Spiegelman BM 1996 IRS-1-mediated inhibition of insulin receptor tyrosine kinase activity in TNF- $\alpha$-and obesity-induced insulin resistance. Science 271 665-668.

Iiboshi Y, Papst PJ, Kawasome H, Hosoi H, Abraham RT, Houghton PJ \& Terada N 1999 Amino acid-dependent control of p70 $70^{\mathrm{skk}}$. Fournal of Biological Chemistry 274 1092-1099.

Iritani N, Fukuda H, Tada K, Itoh A \& Noguchi T 1995 Diet differentially regulates glucokinase and L-type pyruvate kinase gene expression in rat liver. Fournal of Nutrition 125 2945-2652.

Iritani N, Hosomi H, Fukuda H, Tada K \& Ikeda H 1996 Soybean protein suppresses hepatic lipogenic enzyme gene expression in Wistar fatty rats. Fournal of Nutrition 126 380-388.

Ishihara K, Oyaizu S, Fukuchi Y, Mizunoya W, Segawa K, Takahashi M, Mita Y, Fukuya Y, Fushiki T \& Yasumoto K 2003 A soybean peptide isolate diet promotes postprandial carbohydrate oxidation and energy expenditure in type II diabetic mice. Fournal of Nutrition $133752-757$.

Ito Y, Ariga M, Takahashi S-I, Hidaka T \& Noguchi T 1997 Change in tyrosine phosphorylation of insulin receptor and insulin receptor substrate-1 (IRS-1) and association of p85 subunit of phosphatidylinositol 3-kinase with IRS-1 after feeding in rat liver in vivo. Fournal of Endocrinology 154 267-273.

Kanety H, Feinstein R, Papa MZ, Hemi R \& Karasik A 1995 Tumor necrosis factor $\alpha$-induced phosphorylation of insulin receptor substrate-1 (IRS-1). Fournal of Biological Chemistry 270 23780-23784.

Kettelhut IC, Foss MC \& Migliorini RH 1980 Glucose homeostasis in a carnivorous animal (cat) and in rats fed a high-protein diet. American Fournal of Physiology 239 R437-R444.

Lavigne C, Marette A \& Jacques H 2000 Cod and soy proteins compared with casein improved glucose tolerance and insulin sensitivity in rats. American fournal of Physiology 278 E491-E500.

Li J, De Fea K \& Roth RA 1999 Modulation of insulin receptor substrate-1 tyrosine phosphorylation by an Akt/phosphatidylinositol 3-kinase pathway. Fournal of Biological Chemistry 274 9351-9356.

Liu YM, Paz K, Herschkovitz A, Alt A, Tennenbaum T, Sampson SR, Ohba M, Kuroki T, LeRoith D \& Zick Y 2001 Insulin stimulates PKC $\zeta$-mediated phosphorylation of insulin receptor substrate-1 (IRS-1). Fournal of Biological Chemistry 276 14459-14465.

Mothe I \& Van Obberghen E 1996 Phosphorylation of insulin receptor substrate-1 on multiple serine residues, $612,632,662$, and 731, modulates insulin action. Fournal of Biological Chemistry 271 11222-11227.

Nakajima K, Yamauchi K, Shigematsu S, Ikeo S, Komatsu M, Aizawa T \& Hashizume K 2000 Selective attenuation of metabolic branch of insulin receptor down-signaling by high glucose in hepatoma cell line, HepG2. Fournal of Biological Chemistry 275 20880-20886.

Patti M-E, Brambilla E, Luzi L, Landaker EJ \& Kahn CR 1998 Bidirectional modulation of insulin action by amino acids. Fournal of Clinical Investigation 101 1519-1529.

Pederson TM, Kramer DL \& Rondinone CM 2001 Serine/threonine phosphorylation of IRS-1 triggers its degradation. Diabetes $\mathbf{5 0} 24-31$

Peret J, Foustock S, Chanez M, Bois-Joyeux B \& Assan R 1981 Plasma glucagons and insulin concentrations and hepatic phosphoenolpyruvate carboxykinase and pyruvate kinase activities during and upon adaptation of rats to a high protein diet. Fournal of Nutrition 111 1173-1184.

Ravichandran LV, Esposito DL, Chen J \& Quon MJ 2001 Protein kinase $\mathrm{C}-\zeta$ phosphorylates insulin receptor substrate-1 and impairs 
its ability to activate phosphatidylinositol 3-kinase in response to insulin. Fournal of Biological Chemistry 276 3543-3549.

Reis MAB, Carneiro EM, Mello MAR, Boschero AC, Saad MJA \& Velloso LA 1997 Glucose-induced insulin secretion is impaired and insulin-induced phosphorylation of insulin receptor and insulin receptor substrate-1 are increased in protein-deficient rats. Fournal of Nutrition 127 403-410.

Rigalleau V, Aparicio M \& Gin H 1998 Effects of low-protein diets on carbohydrate metabolism and energy expenditure. Fournal of Renal Nutrition 8 175-178.

Rossetti L, Rothman DL, De Fronzo RA \& Shulman GI 1989 Effect of dietary protein on in vivo insulin action and liver glycogen repletion. American Foumal of Physiology 257 E212-E219.

Rui L, Aguirre V, Kim JK, Shulman, GI, Lee A, Corbould A, Dunaif A \& White MF 2001 Insulin/IGF-1 and TNF- $\alpha$ stimulate phosphorylation of IRS-1 at inhibitory Ser307 via distinct pathways. Fournal of Clinical Investigation 107 181-189.

Saltiel AR \& Kahn CR 2001 Insulin signaling and the regulation of glucose and lipid metabolism. Nature 414 799-806.

Sun XJ, Rothenberg P, Kahn CR, Backer JM, Araki E, Wilden PA, Cahill DA, Goldstein BJ \& White MF 1991 Structure of insulin receptor substrate IRS-1 defines a unique signal transduction protein. Nature 352 73-77.

Sun XJ, Goldberg JL, Qiao L \& Mitchell JJ 1999 Insulin-induced insulin receptor substrate- 1 degradation is mediated by the proteasome degradation pathway. Diabetes 48 1359-1364.

Takahashi S, Kajikawa M, Umezawa T, Takahashi S-I, Kato H, Miura T, Nam T-J, Noguchi T \& Naito H 1990 Effect of dietary proteins on the plasma immunoreactive insulin-like growth factor-1/somatomedin C concentration in the rats. British Fournal of Nutrition 63 521-534.
Takano A, Usui I, Haruta T, Kawahara J, Iwata M \& Kobayashi M 2001 Mammalian target of rapamycin pathway regulates insulin signaling via subcellular redistribution of insulin receptor substrate 1 and integrates nutritional signals and metabolic signals of insulin. Molecular and Cellular Biology 21 5050-5062.

Takenaka A, Hirosawa M, Mori M, Yamada S, Miura Y, Takahashi S-I \& Noguchi T 1993 Effect of protein nutrition on the mRNA content of insulin-like growth factor-binding protein-1 in liver and kidney of rats. British fournal of Nutrition 69 73-82.

Tanti J-F, Grémeaux T, Van Obberghen E \& Le Marchand-Brustel Y 1994 Serine/threonine phosphorylation of insulin receptor substrate 1 modulates insulin receptor signaling. Fournal of Biological Chemistry 269 6051-6057.

Tremblay F \& Marette A 2001 Amino acid and insulin signaling via the mTOR/p70 S6 kinase pathway. Fournal of Biological Chemistry $27638052-38060$.

White MF 1998 The IRS-signaling system: a network of docking proteins that mediate insulin action. Molecular and Cellular Biochemistry 182 3-11.

White MF 2002 IRS proteins and the common path to diabetes. American Fournal of Physiology 283 E413-E422.

Yoshizawa F, Kimball SR, Vary TC \& Jefferson LS 1998 Effect of dietary protein on translation initiation in rat skeletal muscle and liver. American fournal of Physiology 275 E814-E820.

Yoshizawa F, Kido T \& Nagasawa T 1999 Stimulative effect of dietary protein on the phosphorylation of p70 S6 kinase in the skeletal muscle and liver of food-deprived rats. Bioscience, Biotechnology, and Biochemistry 63 1803-1805.

Received in final form 16 December 2003 Accepted 13 January 2004 